\title{
WOMEN AND MARRIAGE IN MIDDLEMARCH AND THE RETURN OF THE NATIVE
}

\author{
Najia Asrar Zaidi ${ }^{*}$ \\ Fouzia Rahman Khan ${ }^{* *}$ \\ Saima Manzoor ${ }^{* * *}$
}

\begin{abstract}
Women in the nineteenth century were the worst victims of patriarchy, socio-cultural norms and class difference. It was not a good time for women. In the Victorian era, women did not have the right to vote, own property or come out of the violent marriage. This picture has been painted by many writers of the time. Of all the Victorian novelists, Eliot and Hardy have the gifted ability to chart the women situation from all angles. Both writers show that women had few rights and privileges. The socio-cultural and economic factors further contributed to women's oppression. Women were expected to remain attached to the domestic sphere. Marriage is one such institution, which during the Victorian period became a tool for women's exploitation and subjugation. The heroines and protagonists suffer due to social and moral taboos. Mismatch in marriage leads to several problems for the couple and their respective families. George Eliot in her novel Middlemarch and Thomas Hardy in his work The Return of the Native, portray the heroines who decide to step into life that is just contrary to their expectations and later regret their decisions. This paper would attempt to analyze the repercussions of their choices and compare their nature and the line of action these heroines take to deal with the situation they are placed into.
\end{abstract}

Keywords: Women, marriage, nineteenth century, socio-cultural norms, disillusionment, female agency

\section{Introduction}

The Victorian age was diverse in trends and tendencies. It was rich in movements, inventions, discoveries, and intellectual cravings. During this period British colonies stretched from South-Asian countries to the Island continent of Australia. Britain became the nucleus of the world. The political hegemony in the form of colonization made England economically a prosperous country. Political theorists like Smith ${ }^{1}$ and Bentham ${ }^{2}$ presented their theories of utilitarianism and capitalism. Smith advocated the notion that capitalism was socially, politically and economically more beneficial for the greater good and for the greater number of people at the expense of the poor. Bentham philosophized the doctrine of Laissez faire. It became the philosophy of individualism, liberalism, and

\footnotetext{
* Najia Asrar Zaidi, Ph.D. Associate Professor, Department of English, University of Balochuistan

${ }^{* * *}$ Fouzia Rahman Khan, Assistant Professor, Department of English, Sardar Bahadur Khan Women University

*** Saima Manzoor, Assistant Professor, Department of English, University of Baluchistan

${ }^{1}$ Adam Smith. The Wealth of Nations . (UK: Methuen \& co, 1922)

${ }^{2}$ Jeremy Bentham. An introduction to the principles of morals and legislation . 1789.
} 
utilitarianism. Mill ${ }^{3}$ brought it to the highest point. Industrialization had a deep impact on the social, political and economic fabric of the society. Work was increasingly done by machine rather than by hand. Human power was replaced by energy sources like coal and oil. It greatly reduced the employment opportunities for rural labor force. Industrialization became a force in dismantling family structure and traditional collective unity. People were identified through occupations and economic standing. Darwin's "origin of Species" created confusion and agnosticism amongst people. ${ }^{4}$ Consequently, the atmosphere of gloom and skepticism pervaded in the Victorian society bring restlessness in the lives of people.

Ironically, Victorian period produced great milestones for women and women writers. During this period women realized their subordinated status in the society. Increasingly, the scientists, philosophers and thinkers popularized the thought that creation and production of knowledge had to be free of church authority and religious doctrines. Religion was considered to be the strongest obstacle in the way of enlightenment and freedom of mankind. Consequently, it was pushed to the back burner on the pretext of having no comprehension of the physical world -far removed away from reality. Based on the tenets of rationality and intellectual environment of an age it became fashionable to challenge religious dogmas and place trust in science. It proved a serious blow to social relations and family values.

This situation ignited in women the desire to fight for human rights and get independence from arbitrary structures that have restricted their lives and break the clutches of domesticity and enslavement by men. Intellectuals like Wollstonecraft ${ }^{5}$ had forcefully attacked patriarchy and advocated for the education of women. In her well-known work "Thought on Education of Daughters". She regrets that women failed "to engage their attention and render it an employment of the mind". Class structure further contributed to the seriousness of the situation. Upper class girls were privately tutored as seen in Jane Eyre. Middleclass girls were also home-tutored and sent to school at times as mentioned in Austen's Emma and Bronte's Wuthering Heights. Unfortunately, the daughters of working class were trained to become obedient maids and devoted wives to poor husbands. The last thirty years of nineteenth century introduced legislation on education and legal rights of married woman since, women like property were owned by men, "the absolute master of her, her property and her children".

Legislation in the form of reform acts positively impacted women's status in the society of the time. These acts blessed women with property and marriage rights upon marriage, which ultimately strengthened women's position in marriage. Perkins ${ }^{7}$ points out' husband and wife were considered one person in Law - and that person was he'. The Victorian period was quite sensitive towards conventional morality and especially in the

\footnotetext{
${ }^{3}$ John Mill Stuat. Essays on Economics and Society. (London: Roultedge, 1967).

${ }^{4}$ Charles Darwin. On the origin of species. By means of natural selection. (London: John Murray, 1859).

${ }^{5}$ Mary Wollstonecraft,. Thought on education of daughters: With reflection on female conduct, in more important duties of life. (London: Johnson, 1978, 25)

${ }^{6}$ Francois Basch. Relative creatures: Victorian Women in Society and the Novel. (New York: Shocken, 1974)

${ }^{7}$ Joan Perkins,. Victorian women. (London: Cambridge, 1993)
} 
case women had to bear the burden - 'of gendered morality' (Growing 1996) ${ }^{8}$. However, social and moral factors continued to exercise formidable influence over women. Morgan $^{9}$ in her well-known work "A Victorian Woman's place" explains that the political situation also pressurized women to become torch-bearers of British values and norms, a "a part of the myth of the Britain's civilizing mission abroad". Women were to moralize, and also civilize and create a public spirit in their children. According to Malius, "Since a physical component, the moral sense is supposed to temper and refine brute sexual urge in human-beings, talk about a culture's moral condition is usually talk about its sexual arrangements and attitudes, that part of culture which influences sexuality and shapes even physicality of a people". ${ }^{10}$

To save the society from moral and sexual decay, the Victorian society believed to establish middle-class norms through regulating women's behavior. This conventional and gendered morality did not apply to men. Domestic anxieties kept women engaged and they did not worry to read widely and write productively. Characteristics like docility, meekness and self-sacrifice were highly admired in women. This paper aims to explore women situation and the institution of marriage in nineteenth century England. The paper will throw light that how lack of self-knowledge and self-ignorance leads to complications in marriage in Eliot's Middlemarch and Hardy's The Return of the Native. Women's engagement with their prospective husbands, show how the romantic aspirations fall short of their expectations and they become victims of unfulfilled hopes. The reaction of the protagonists will define their coping skills and the way they acculturate or fail to compromise.

\section{Conceptual Framework}

Victorian and women go together. This period is credited and honored to set the stage for initiating dialogue between women's literary tradition- and Victorian patriarchs. As far as literary history of women's progress and its vision is concerned, it proved to be the best time for women writers and writings on women. It was also the worst time for womensince, society defined women in relation to men which led to the complete denial of woman's existence. Owing to this very fact, Mary Ann Evans used pseudonym (George Eliot) to publish her novels. This name became her identity card and the world does not seem to care anymore for her real name. A notable figure of $19^{\text {th }}$ century England, G.H. Lewes, quoted in Showalter argues, “...the Literature of women has fallen short of its functions owing to a natural and a very explicable weakness-it has been too much a literature of imitation. To write as men write is the aim and besetting sin of women; to write as women is the real task they have to perform". Lewes remarks served as a wakeup call which opened the flood gates of women writers in Victorian England. Thus, it initiated an articulation of women's experiences contesting male cultural imperialism and as Showalter" ${ }^{11}$ states, "it seemed that nineteenth century was the Age of the Female

\footnotetext{
${ }^{8}$ Laura Growing,. Domestic Dangers. (USA: AMazon, 1996)

${ }^{9}$ Simon Morgan. A victorian woman's place. Public culture in the nineteenth century. (New York: Taurus Academy, 2007)

${ }^{10}$ Jill Malius, Unstable Bodies: Victorian Representations of Sexuality and Maternity. (Manchester: UP, 1995).

${ }^{11}$ Elaine Showalter. A Literature of their Own. British Women Writers from Charlotte Bronte to Doris Lessing. (UK: Virago Press, 1977) 5-6
} 
Novelist". Starting with Victorian period, Showalter has classified women writings into three phases. Feminine Phase ranges from 1840-1880. Writers like Bronte sisters and Eliot already mentioned, used pseudonyms to establish themselves as writers and gain entry into the publishing world. During this phase, women writers imitated male artistic style and their aesthetic standard. This style was generally derivative. The feminist phase from 1880-1920 induced separatist and aggressive positions is taken up by women writers. Finally, Female Phase 1920-onwards particularly explores and minutely examines female writing and experience. Though, nineteenth century fiction portrays women confined in homes and restricted especially in the work of Dickens, Bronte sisters, Eliot and Hardy: yet, the writings by Eliot and Hardy established them as torch bearers of the period they lived in.

Showalter's ${ }^{12}$ contribution to women's studies is immense. She forwards the idea that 'feminist criticism has never been a unified theory. There are no specific entry points indicative of beginning theory or feminist criticism. It rather has a broad communitybased intellectual base, not limited to a certain country, genre and age. Such dispersed meditations have strengths and weaknesses as well. Debate on this issue does not fall within the purview of this paper. Showalter ${ }^{13}$ has categorized modern feminist criticism into two distinct modes. First mode examines women as writers. This includes various genres, themes, style and so on. The second mode pertains to the feminist as the reader which according to her is highly ideological. The advantage of this mode is to read, scrutinize and analyze the image of women as portrayed in a certain work whether stereotypical or highly individualized. Therefore, the researchers would use the second mode as a method to interpret the data extracted from the texts selected for this paper. Furthermore, Showalter firmly believes that it enables the reader to explore new meaning or draw different conclusions from any work on women. It also gives freedom to the readers to ask new questions with feminist lens on, and from the perspective of $21^{\text {st }}$ century. In this context, Belsey and Moore ${ }^{14}$ claim that purpose of reading any of text may not be to blame or praise it but in their view all interpretation is political. When studying any text, therefore, a feminist reader needs to be constantly asking, how it represents woman, what it says about gender relations and how it defines sexual difference.

Based on above discussion, the researchers have selected the novels of Eliot and Hardy to examine the way they represent the status and position of women in Victorian society. Both writers have more similarities than differences. George Eliot was an intellectual who had certain rich areas of her mind devoted to philosophy, science, culture, religion, society and women. Her exposure to such diverse fields added plurality to her vision and was God-gifted with the ability to view a situation and woman's experience from all possible angles. In the words of Showalter "Eliot was reserved, inaccessible, and opaque. In her maturity she violated the values of sisterly communion in the female subculture by

\footnotetext{
${ }^{12}$ Elaine Showalter. Women's Time, Women's Space: Writing the History of Feminist Criticism. Tulsa Studies in Women's Literature. 3 (1984) :29-43

${ }^{13}$ Elaine Showalter. Feminist Criticism in the Wilderness: Modern Criticism and Theory: A Reader.Daved Lodge with Nigel Wood (Harlow: Pearson Education, 2000), 308-309

${ }^{14}$ Catherine Belsey and Jane Moore, eds. Introduction: The Story So Far. The Feminist Reader. Essays in

Gender and Politics of Literary Criticism. (London: Macmillan, 1993), 1-20
} 
avoiding close friendships with other women writers". ${ }^{15}$ During that period, she had the courage to violate the rules of a conservative, traditional society by openly living with a man and not being married to him(Lewes, mentioned above). She is highly tributed in Mrs. Olphiant's Autobiography, quoted in Showlater in these words, "She was so consciously George Eliot- so interpenetrated head and heal, inside and out, with the sense of her importance as the great novelist and profound thinker of her generation, so as to make her society a little overwhelming, leaving us baser creatures the impression of having been rolled very flat indeed. Though, Dorothy Richardson quoted in Showalter felt she wrote 'like a man'. This study proposes to study George Eliot's masterpiece Middlemarch (1852). We trace the elements of women emancipation from patriarchal control as depicted in the novel and analyze the struggle of the protagonist from beginning to the end with the lens of theoretical constructs embedded in first and second wave feminism with some aspects falling into the third. An interesting question can be raised that why we have chosen Hardy an novel for the article since he is a not a woman? We believe that ignoring Hardy's contribution to Feminism is then not doing justice with women and Victorian period. Showalter praises Hardy, Moore and Gissing as they "imagined a New woman who fulfilled their own fantasies of sexual freedom ----and took the idea of female influence seriously, and they intended to make it a genuine source of power" . Hardy like his contemporary Eliot increasingly focused on woman question and issues relating marriage and sexual relations. He remained very unconventional in the use of his Language for woman as well as in his treatment of topics relating women. Being a man he has great sympathy for his female protagonists. Secondly, Hardy is a close contemporary of Eliot and both share various elements of philosophy relating the environment of the time. Their unconventional beliefs and practices also bind them. Third, Hardy's female protagonists have significantly contributed towards feminism. Both developed a vision for women at the time which was toughest for them and spotted the areas that needed meticulous cleansing, so that women can have an identity of their own.

\section{Methodology}

This article is based on the close textual analysis of Middlemarch (2000) by George Eliot and The Return of the Native by (1996) Thomas Hardy. In this context, primary data is collected from the above mentioned texts and further analyzed by the secondary data to support the researcher's point of view. The techniques of close reading is used to analyze data, Since Belsey believes that text as a tissue of signifier make certain demands on the textual analyst, and provides the material for analysis. ${ }^{16} \mathrm{~A}$ thread of a story remains connected to many strands which may lead to multiple meanings of the text. Hence, a text can have multiple interpretations. The meaning remains undecided. During this exercise of meaning extraction the readers may find some aspects as already explored by earlier researchers and at the same time generate new data which has not been brought to light previously. Thus, it could be a mixture of both. There is no final word on the text. The process continues.

\footnotetext{
${ }^{15}$ Elaine Showalter. A Literature of their Own. British Women Writers from Charlotte Bronte to Doris Lessing. (UK: Virago Press, 1977) 88-89

${ }^{16}$ Gabriele Griffin. Research Methods for English studies. (New Delhi: Rawat Publication. 2007)
} 


\section{Research Questions}

The two novels selected for the study and data extracted from the respective texts on the issue covering women and the institution of marriage would then center on the following questions:

- How the two selected writers represent $19^{\text {th }}$ century women and the institution of marriage in Middlemarch and The Return of the Native?

- In what way the protagonists' react to disillusionment and disappointment in marriage and spot the agency to survive in the male dominated world?

\section{Discussion}

George Eliot the writer of six novels is well known for her high intellectual caliber, and great literary talents with knowledge in various fields. As already mentioned Victorian age was an age of contradictions and so was Eliot's nature and her philosophy as reflected in her novels. Her life has various shades and can be studied using various lenses. She earned her own living and never depended on any of her male family members. Interestingly, she was courageous enough to live with George Lewes without tying the wedding knot. Despite living an unusual life style, she portrays womanhood in traditional colors. Eliot's masterpiece Middlemarch narrates the life of women from September 1829-through 1832 with special focus on women's weaknesses, expectations, dilemmas, and capacities with which to rise and meet the world. Dorothea has higher ideals in life. Talking about her heroine, Eliot narrates, "She could not reconcile the anxieties of a spiritual life involving eternal consequences--- and artificial profusions of drapery. Her mind was theocratic, and yearned by its nature after some lofty conception of the world, which might frankly include the parish of Tipton and her own rule of conduct there---. ${ }^{17}$

The passage clearly tells the difference in nature of Dorothea and Celia. The length of this paragraph shows how completely the writer reports on her protagonist, her nature, surroundings and commitments in life. The author just like Jane Austen analyzes the situation from all angles to indicate about the selection of a heroine who though beautiful is jumping into a life that cannot be dictated by one's own whims and desires. Her theocratic nature is compared to St. Theresa as she writes, "What was truly remarkable about St. Theresa (and this must be why she is the prelude) is that she was a woman who was famous both for her ecstatic mystical visions and also for her practical, this worldly success in reforming the day to day life of an order of nuns. To have achieved both of these things would suggest that St. Theresa indeed must have lived a life that was for her unified in all its aspects, from the minutely mundane (a ground life here- now-in England) to the transcendently spiritual". ${ }^{18}$ These lines are clearly suggestive of some contradictions in the character of the heroine who at this time of life is not aware of dimensions that her personality may develop in future. Not having proper education and

\footnotetext{
${ }^{17}$ George Eliot. Middlesmarch (London: Wordsworth, 2000)
}

${ }^{18}$ Ibid. 179 
worthy project in life then Dorathea suffers and struggles to gain identity by opting for something which immortalizes her and can leave a legacy behind. Blake associates this with" lack of vocation as tenuousness of identity". ${ }^{19}$ Therefore, she is passionately in a process to define her vision of life.

Drawing the parallels, Eliot proceeds towards the changes coming in Pre-Victorian England where it might get difficult for Dorothea Brooke "to remain attached to some object which would never justify weariness". ${ }^{20}$ Hence, joining the spiritual; with the real could become an arduous task for her heroine. Adams ${ }^{21}$ rightly comments, "The heroine is young, immature and her nature unformed". She would spend nights reading theological books, and planning her next action for the good of all. She is proposed by Sir James. She rejects him feeling that he lacks spirituality and knowledge. This makes him unimpressive in her eyes. In this context, Beer $^{22}$ comments, "Dorothea finds it hard to distinguish between love and learning: this is a problem which bears particularly hard on women. The mentor-pupil relationship in its male-female form presents the man as teacher and the woman as pupils. The pattern traditionally extends across intellectual and sexual experience. Her thirst for knowledge and hunger to serve humanity blinds her to many flaws that Mr. Casaubon is attached with". On the other hand, Casaubon desires to marry her to adorn his life with the companionship of a young girl, who can passionately serve him in the last years of his life. He derives sense of contentment from the thought that since he "wants a highly educated dog, whose devotedness would serve him well in his project to enlighten the world. ----Dorothea appears to fit the bill", ${ }^{23}$

She soon gets disillusioned with her marriage on realizing not being loved, respected and valued. She feels lonely, confused and life becomes "like a disease of retina". ${ }^{24}$ Casaubon remains absorbed in his own work and ignores her presence entirely. Eliot contrasts their nature in these words, "what was fresh to her mind was worn out to his-----a lifeless embalmment of knowledge. ${ }^{25}$ During their tour to Italy Dorothea offers to help him with his studies but Casaubon feels offended and interprets it as "a spy watching with everything like a malign power of inference". ${ }^{26}$ Casaubon is threatened by his wife's confidence and this sense of insecurity in both partners devoid their relationship of trust and pity for each other. Casaubon's indifference towards his wife is well phrased in the words of Neale, ${ }^{27}$ "He cannot abandon his own egoism and recognize the individuality of the person he has married". Dorothea suffers from unfulfilled expectations of married life and her ideas of spiritual life dash to ground leaving her shattered, torn and helpless. This 'gentlewoman's oppressive liberty' begins to kill her morally and mentally. She dreams

${ }^{19}$ Blake, Kathleen. Middlemarch and the Women Question, Nineteenth Century Fiction, 31(3), (California:

University of California Press, 1976), p.280

${ }^{20}$ Ibid., 3

${ }^{21}$ Harriet Farewell Adams . "Dorothea and Miss Brooke in Middlemarch. ." Nineteenth Century Fiction (39,

No. 1 (1984): 69-90).

${ }^{22}$ Gillian Beer. George Eliot. (Indiana:Bloomington, 1986)

${ }^{23}$ Clifford J Marks. Middlemarch Obligations and Dorothea's Duplicity. Rocky Mountain Review of Language and Literature (2000): 31.

${ }^{24}$ Eliot, George. "Middlemarch." 29-30. (London: Penguin, 2000), p.16

${ }^{25}$ Ibid., 164

${ }^{26}$ Ibid., 167

${ }^{27}$ Neale, Catherine. Middle March. Penguine Critical Studies. London: Penguin, 1989 
that "if he would have held her hands between his and listened with the delight of tenderness and understanding to all the little histories which made up her experience". ${ }^{28}$ Casaubon's total alienation from her and their marriage creates a sense of imprisonment in her. Dorothea becomes conscious of the uselessness of her marriage and starts questioning its meaninglessness, "Her blooming full-pulsed youth stood there in a moral imprisonment which made itself one with the chill, colorless, narrowed landscape, with the shrunken furniture, the never read books, and the ghostly stag in a pale fantastic world that seems to be vanishing from the daylight. ${ }^{29}$

"The arrival of Will (Casaubon's cousin) on the scene disturbs their relationship more. Dorothea meets him first in Italy and the situation becomes critical for the couple when Will Ladislaw's letter announces his visit and Casaubon expresses his severe discomfort followed by a severe heart attack. As a dutiful wife she avoids meeting Ladislaw and behaves in a submissive way to prevent argument, which may hurt his feelings more. She sacrifices her ego and desires for the sake of her marriage. Her husband requests her to make a promise of fulfilling his mission after his death. Not knowing the contents fully she takes time to think. After his death, she comes to know about this will stating that her marriage to Will would disinherit her completely. She feels disgusted, surprised, and stabbed by dead husband's jealousy and mistrust of her. To her dismay, she feels "drawn or her yearning of the heart "towards Will". ${ }^{30}$ Finally, she comes out of imprisonment and makes the right choice by marrying Will Ladislaw.

Dorothea had earnestly desired to secure a respectable place in society by marrying Casaubon and to assist him in his work on theology. Mistrust and egocentric attitude of her husband increasingly gives her sense of dislocation in the new surroundings. Therefore, this sense of deprivation, degradation and humiliation strengthens her will to search for her self-hood. She realizes that serving this man to any extent would not satisy him and yearns to be loved. Rigid attitude of her husband brings the passionate woman to life. Her life with Casaubon teaches her many lessons and awakens independent thought in her. It is slightly suggestive of the tendencies present in third wave feminist criticism which according to Sorensen \& Krolokke ${ }^{31}$ "honor contradictory experiences and deconstruct categorical thinking". Cassaubon's efforts to contain her passion fail. Dorothea comes out of the situation as Victorious and self-affirmed.

Hardy is another important voice from Victorian period that shakes the fabric of conventional morality and rigid class norms which played havoc with the life of common person in rural England and especially women. He was born in 1837 at the time when revolutionary changes were taking place in Victorian England. Literature during this period according to Richard ${ }^{32}$ "the record of a society seeking ways to adjust itself to conditions as revolutionary as any we face today". Coming to read Hardy's "Return of

${ }^{28}$ Ibid., 165

${ }^{29}$ Ibid., 227

${ }^{30}$ George Eliot. "Middlemarch." (London: Penguin, 2000)

${ }^{31}$ Anne Sorensen,.Scott.\& Charlotte Krolokke. Gender Communication Theories and Analyses.-From silence to Performance.(London:SAGE, 2005).

${ }^{32}$ Daniel Richard,. Victorian Peopleand Ideas: A comparison for the readers of Victorian Literature. (New York, 1973) 
the Native" after Middlemarch is like stepping out of the sheltered court-yard in a hailstorm with no umbrella and being badly pelted by multiple themes of passionate love, false expectations, class distinction, gender discrimination and so on. At the outset of the novel, Eustacia's father and grandfather are introduced as such, "But he did his best; made Budsmouth permanently his home, took great trouble with the child's education, the expenses of which were defrayed by the grandfather, and throve as the chief local musician till her mother's death, when he left off thriving, drank and died also. The girl was left to the care of the grandfather, who, since three of his ribs came broken in a shipwreck, had lived in this airy perch on Egdon, a spot which had taken his fancy because a remote blue tinge on the horizon between the hills, visible from the cottage door, was traditionally to be the English Channel. ${ }^{33}$

Circumstances take Eustacia Vye out of Budsmouth and push her into her grandfather's lap. Luckily, her father has taken care of her education, but she cannot entirely live according to her own wishes. Her first introduction identifies her in relation to Heath. The text says. "There the form stood, motionless on the hill beneath. Above the plain rose the hill, above the hill rose the barrow, above the barrow rose the figure. Above the figure was nothing that could be mapped elsewhere than on a celestial globe. Such a perfect, delicate and necessary finish did the figure give to the dark pile of hills that it seemed to be the only obvious justification of their outline". 34

Eustaciaa Vye is an integral part of Heath and hates Heath. "Egdon was her hades, and since coming there she had imbibed much of what was dark in its tone, through inwardly and eternally unreconciled threats. Her appearance accorded well with this smouldering rebelliousness and the shady splendor of her beauty". "Heath and Eustacia have absorbed each other so much so fully that neither would not let the others live independently. About Hardyan novel (Peck 1987, 22) ${ }^{36}$ writes, "You should always be able to find Evidence of a society versus nature tension at the heart of the maternal---the first thing that might strike you is that Edgon Heath must in some way represent nature; even at the outset it seems reasonable to speculate that the order of the society will be set against the heath. The characters who live here are likely to be caught between the pull of the society and the pull of the nature". Eustacia is a beautiful passionate woman just the opposite of Dorothea Brooke. Her passionate nature is described in sexual terms as 'full limbed' 'with two matchless lips'. "To be loved to madness -such was her great desire. Love was to her the one cordial that which could drive away the eating loneliness of her days. And she seemed to long for the abstraction called passionate love more than any particular lover". 37 Time and circumstances strengthens her desire to love someone. On Egdon, 'coldest and meanest kisses were at meanest prices; and where was the mouth matching hers to be found' ${ }^{38}$ These lines then pose a question. Was she ready to love? Has time enabled her to sacrifice, compromise and still remain persistent? Was she aware of the sufferings that love initiates for the lovers and the conflicts it creates with the society?

\footnotetext{
${ }^{33}$ Hardy, Thomas. The Return of the Native.( London: Penguin, 1999), p.70

${ }^{34}$ Ibid. p. 17

${ }^{35}$ Ibid. p. 69

${ }^{36}$ JohnPeck . How to study a Thomas hardy Novel . (New York: Macmillan, 1987)

${ }^{37}$ Ibid. p. 71

${ }^{38}$ Hardy, T. Op.cit., p.71
} 
Was she ready to remain loyal at all costs? Hardy answers all these questions as the story unfolds.

For her no one living on the heath deserves her. The ensuing passage throws light on her concept of love. "Fidelity in love for fidelity's sake has less attraction for her than for most women: fidelity because of love's grip had much. A blaze of love and extinction was better than a lantern glimmer of the same which should last long years". ${ }^{39}$ Clearly, Eustacia's values are in stark contrast with that of the society. "Her instincts towards social nonconformity were at the root of this". ${ }^{40}$

This rebelliousness in her can be judged from her eyes that signify 'self-absorption and disregard of others. "She had pagan eyes full of nocturnal mysteries. Their light as it came and went, and came again, was partially hampered by their oppressive lids and lashes; and of these the under lid was much fuller than it usually is with the English women. This enabled her to indulge in reverie without seeming to do so: she might have been capable of sleeping without closing them up". ${ }^{41}$ Living in heath with nothing to do makes her long for a companion. It is in these circumstances she meets Damon Wildeve, an engineer by profession but runs an Inn. He is not a man of sound character and is known for having multiple affairs with women. Eustacia knows he is not the right choice but longs for him as to kill her idleness and yearns for a person who is an embodiment of romance and passion. The story takes an interesting turn when Clym Yeobright returns to Heath. He runs a diamond business in Paris, is well-educated, having good family background. This provides her with enough material to fill her vision and animate her existence. Rapturous ecstasy filled the air around her. For her Clym is directly "coming from heaven". Unable to control her high spirits she visits Mrs. Yeobright and is greeted by Clym. She wonders what attracts him to Heath. Knowing the simple life style of the Yeobrights'- her grandfather warns her that she would despise their modesty and humility. Clym is described through her eyes as, "A handsome man- thoughtful man". Despite this discouragement from her grandfather she remains determined to love him since he is exceptional, thoughtful and handsome.

Eustacia's arrogance forces her not to give up on Clym and follow him without knowing him. She feels that the time and the person has arrived to love. Like (Austen 1815) Emma and Eliot's Miss Brooke she feels Clym to be the best choice in the present context. This attitude shows complete disregard of Clym, his mother. She dreams of going to Paris with Clym leaving this world of darkness and ignorance for fashion, love, luxuries of Paris. This marriage just like that of Miss Brooke and Casaubon is based on wrong expectations. Clym despite the opposition from Mrs. Yeobright (his mother) presents his reasons to her. He expects Eustacia to help him in his study project. "The young woman comes unconsciously to love the being who is destined to occupy the void within her soul, while Clym goes forth to find companion who should become the help-mate he seeks in his projects of study and instruction. The preparation is, therefore, ideal, solitary,

\footnotetext{
${ }^{39}$ Ibid. p. 72

${ }^{40}$ Ibid.

${ }^{41}$ Ibid. p.68
} 
and imaginative". ${ }^{42}$ Similarly, Eustacia is too keen to marry Clym and shares this with him, "Ah you don't know. You have seen more than I, and have been into cities and among people that I have only heard of, and have lived more years than I; but yet I am older at this than you. I loved another man once, and now I love you'--- But I do not think I shall be the one who wearies first. It will, I fear end in this way: your mother will find out that you meet, me, and she will influence you against me'. ${ }^{43}$

The above quoted passages are reflective of the personalities of both protagonists, since they have different aims in life but are being deceived by their obsession to reach certain ideals in life. For Eustacia Clym symoblises modernity. Then love luxury and cosmopolitan experiences would become the focus of their life. On receiving marriage proposal from him she insists, "At present speak of Paris to me. Is there any place like it on earth" (ibid 195). Realizing the desire for the modern world in her voice, Clym says, You are ambitious, Eustacia- no, not exactly ambitious, luxurious. I ought to be of the same vein, to make you happy, I suppose. And yet, far from that, I could live and die in a hermitage here, with proper work to do (ibid, 197). Eustacia, however, misleads and misreads him saying," Don't mistake me, Clym: though I should like Paris, I love you for yourself alone". She deceives Clym to achieve her selfish ends. It is revealed by the writer as such, "Often at their meetings a word or a sigh would escape her. It meant that though she made no conditions as to his return to the French capital, this was what she secretly longed for in the event of marriage: and it robbed him of many an otherwise pleasant hour. $^{44}$

Shortly, after their marriage they realize incompatibility of this companionship. Both live in the world of their own failing to fulfill the expected requirements of companionship. During this period "she was hoping for the time when, as the mistress of some pretty establishment, however small, in Paris, she would be passing her days on the skirts at least of the gay world, and catching stray wafts from those town pleasures she was so well fitted to enjoy. Yet Yeobright was as firm in the contrary intention as if the tendency of marriage were rather to develop the fantasies of young philanthropy then to sweep them away". 45 Dreams of Paris occupy her mind and reading how to establish a school keeps Clym engaged. Misunderstandings between Eustacia and Mrs. Yeobright rise with time. Seriously worried by this ugly situation, she again tries to persuade Clym to move to Paris. "Yes take me to Paris, and go on with your old occupations, Clym! I don't mind how humbly we live there at first, if it can only be Paris, and not Egdon Heath". But I have quite given up that idea, said Yeobright, with surprise. Surely I never led you to expect such a thing?' I own it. Yet there are thoughts which cannot be kept out of mind, and that was mine. Must I not have a voice in the matter, now I am your wife and sharer of your own doom? ${ }^{46}$ At another place she laments, "Yes, I fear we are cooling- I see it as well as you.' She sighed mournfully. 'And how madly we loved two months ago!'

${ }^{42}$ Ibid. p. 73

${ }^{43}$ Ibid. p. 195

${ }^{44}$ Ibid. p. 199

${ }^{45}$ Ibid., p. 236

${ }^{46}$ Ibid., p.242 
Excessive reading badly affects Yeobright's eyes. Her fears turn into a horrifying sight to find him engaged in 'furze cutting'. She sees her marriage with him as 'worse luck'. ${ }^{77}$

Gradually her love for Clym fades into regret. Clym feels that she never understood him right 'marrying in haste an unfortunate man'. His philosophy is beautifully outlined by the (Daleski 1997, 250) in these words," There is nothing particularly great in its greatest walks, and therefore nothing particularly small in mine furze- cutting" ${ }^{48}$ Daleski further says, "The figure is reinforced by the metaphorical blindness on both sides that marks the coming together of this mutual pair---Clym and Eustacia each see the other through the lens of the immediate personal needs. Eusatcia's passion for Clym is the blindness of her need" (ibid 88).She fails to convince Clym to change his mind and eventually loses hope of going to Paris. Clyms commitment and coldness absorbs Eustacia'a aggression and passion. On the other hand, Clym's cousin Thomasin married to Damon Wideve is just the opposite of Eustacia in every way. Though, Damon apparently nice to Thomasin is inherently a self-centered man. He deceives Thomasin and starts flirting with Eustacia. The meetings between Thomasin and Eustacia become more frequent which disturbs the peace at home. The following conversation points to the way Wild eve treats his wife at home.

Damon, where have you been? I was getting quite frightened, and thought you had fallen into the river. I dislike being in the house by myself'. Frightened? He said, touching her cheek as if she were domestic animal. Why, I thought nothing could frighten you. It is that you are getting proud, I am sure, and don't like living since we have risen above our business. Well, it is a tedious matter, this getting a new house---No- I don't mind waitingI would rather stay here twelve months longer than run any risk with baby. But I don't like your vanishing so in the evenings. There's something on your mind- I know there is, Damon. You go about so gloomily, and look at the heath as if it were somebody's goal instead of a nice wild place to walk in'. (ibid 340)

It can be gathered through this conversation that Wildeve is not sincere with his wife and treats her like some domestic animal. Thomasin is a typical housewife who remains concerned for her husband's safety. Unlike Eustacia, she is loyal and faithful to her husband. However, Eustacia is aggressive and romantic. Thomasin considers herself to be the daughter of the soil (Heath) whereas, for the Protagonist it becomes 'unbearable' and is in serious conflict with the environment - her surroundings. Accepting the reality that Clym would not make her dreams come true, she decides to go back to her "village picnic---to dance". ${ }^{49}$ In a way 'she loses respect for her husband' ${ }^{50}$ At this village dance, she comes across Wildeve and this rekindles his loves in her heart. She dances with Wildeve and feels" How near she was to Wildeve! It was terrible to think of. She could feel his breathing, and he, of course, could feel hers". ${ }^{51}$ During this period, Mrs. Yeobright comes to her place for reconciliation but the closed door disappoints her and is

\footnotetext{
${ }^{47}$ Ibid., p. 249

${ }^{48}$ Daleski, Matthew Hillel. Thomas Hardy and Paradoxes of love. (Columbia: Columbia University of Missouri, 1997), p.250

${ }^{49}$ Ibid., p.251

${ }^{50} \mathrm{Ibid}$.

${ }^{51}$ Ibid., p.93
} 
"bitten by adder". She dies on her way back home. When Clym comes to know that Eustacia caused her death, he reacts strongly, "You have held happiness in the hollow of your hand, and like a devil you have dashed it down!". 52

In response she states, "This marriage is as miserable as death". Later, she also contemplates suicide but the pistol has been removed by Charley who works for her grandfather. Though Clym writes a letter to Eustacia for reconciliation, which her grandfather doesn't care to hand it over to her, thinking her too tired to read at that hour. In the morning she is gone. Confused, undecided and depressed she decides to elope with Damon Wildeve. She wants him to take her to Budsmouth.

All through this sojourn she feels sorry for herself only, feels her plans have taken a wrong turn and never regrets her callous behavior in marriage. When she leaves the house the writer signals the tragedy her decision might follow. "the gloom of the night was funereal; all nature seemed clothed in crape.$^{53}$ However, Thomasin comes to inform Clym that Eustacia had eloped with Wildeve. They all set out together to save them from this disaster. But they hear water splashing which signals some mysterious activity. Since, Thomasin is accompanied by Clym and Diggory Venn, they immediately jump into the water to find that Eustacia and Wildeve are already dead. Clym blames himself for the death. He fails to pay heed to the fact that Eustcaia would never have adapted the life he had chosen for her. Similarly, Eustacia never realizes Clym was never the right person for her. He was an educationist with a vision and wanted a wife who would devote life to his cause. This marriage was a great mismatch. Sengupta ${ }^{54}$ calls this novel as Eustacia's Love's tragedy. She writes, "Hers is essentially love's tragedy. Caught between the flaws of her own character, and those of Clym and his mother and in the mashes of mate, she comes to her ruin. But even after all this has been said, there is certain grandeur in her character. There is nothing mean or abject about her. Even in death there is an aura of dignity about her".

Eustacia embodies the rejection of the ideological principles of the society. She is a rebel who explicitly voices the philosophy of sensuousness in her closed society and daringly decisive in what she thinks is right. Realizing the futility of her marriage with Clym, she re-blows air into her lost relationship with Damon. Her meeting with Damon has sexual connotations too. Being passionate and sensuous to extreme, she plans to elope with him but ultimately faces death to mourn her grandeur. Manzoor \& Zaidi ${ }^{55}$ rightly comment, 'If Wildeve, being a man, can be non-serious in the matter of love then why cannot Eustacia be?' That is Hardy's final judgement. Hardy, however, laments the death of a woman who persistently remains glued to her ideals till her end, and leaves the message that she is ready to embrace death but not change her vision of life- the vision that she cannot let society regulate her behavior. She does not allow anyone to define social parameters for her irrational desires and rejects to live in the shackles of the nineteenth

${ }^{52}$ Ibid., p.318

${ }^{53}$ Ibid., p.345

${ }^{54}$ Chittaranjan Sengupta,. Thomas Hardy: The novelist of Tragic Vision. (New Dehli: Bahri Publications, 1994 42).

${ }^{55}$ Saima Manzoor, and Najia Zaidi. Hardy's Unequivocal and obsessive Association with Gender Issues.

Baluchistan Review, XXXV no 2,(2016):100-115 
century England. Hence, portraying his heroine in various moods as free spirited, sensual, and self-determined then points to the fact that women like man can also fall short of perfection. This indicates that he shares certain elements with second and third wave feminists who value those women who create stir in the society of their time and pursue ideals contrary to societal expectations.

\section{Conclusion}

Middlemarch and Return of the Native detail certain hopes and dreams that women expect from their marriages. Both writers highlight the circumstances women are placed in and the options available to them in affairs relating marriage. Society approves those marital choices, which are according to the dictates of culture and norms. It is unimaginable for eighteenth century England that a young girl like Dorothea Brooke can marry a man, who is double her age, very mature and devoid of emotions-only connected with his work and commitments. There are illusions and weaknesses on both sides. Despite the obstacles in the way, Dorothea and Casaubon get married. This union makes them realize the disillusionment in marriage. These sour experiences in marriage make them adopt various courses in life. Dorothea Brooke tries to continue with Casaubon despite learning about his intentions. She feels the world is cruel and grim. Realities of life cannot be altered and that marriage as a social institution can at times become more threatening for women and fails to protect them. However, her accommodating gestures strengthens the inner dimensions of her personality to help her move toward's establishing her identity as an independent person of the society. Her marriage with Casaubon lets her explore her womanhood and selfhood from all dimensions. Challenging the norms of the society, she marries twice and each time marries the person of her choice. This points out toward female agency even in pre-Victorian England.

Eustacia is an obstinate woman. Her sufferings in marriage do not teach her to mature. In fact, she expects her husband to change and accommodate her needs. On the other hand, she develops resistance identity with respect to the culture of her time. She does not compromise in her quest for independence and freedom to live her way. Daringly, she rejects to be identified in relation to men but expects them to be identified in relation to her. To this end, she uses her sexual agency to control and manipulate men. She just remains attached to lust and wealth till the last moment $f$ her life. Schwartz ${ }^{56}$ rightly says, "Hardy's endings confirm rather than transfigure what proceeds and reject the notion that experience brings wisdom and maturity". Eustacia dies because she cannot live in a world which does not serve her needs and accommodate her demands. Being fiercely independent and with a desire to determine her own destiny leads her towards her death. She remains materialistic till the end and her death announces her self-determining existence.

Eliot shows that a bad marriage can teach a lot to a woman who has the ability to learn, adapt and never to lose hope. Shortsightedness in selection of her marriage partner reveals that Dorothea's decision was made in haste. Time and wisdom favor Dorothea.

\footnotetext{
${ }^{56}$ Schwartz, Danial R. The transformation of English Novel 1890-1930 studies in Hardy, Conrad, Joyce,
} lawrence, Forster, Woolf. 2nd Edition. (London: McMillan, 1995). 
Her husband dies and she is released from this oppressive marriage. Morgan says, "Dorothea's release from that oppressive marriage is a gift", ${ }^{57}$ the gift for her patience, endurance and balanced vision of life. Dorothea realizes that ideal wishes and ideal world are deceptive and she has to return to the world of reality to mature, cope and survive. She learns to amend her idealistic and spiritual notions of marriage.

Eliot and Hardy remained obsessively associated to women and society. Both writers reject traditional all-knowing power, i.e. structures of women oppression. They aggressively fight the case of women to change the whole way of thinking about them. They put women at the center of their work. Both distance themselves from the society they were living in. Through their work they criticize the norms, values that exploit and oppress women. Both writers are critical of male characters in their novels and strongly condemn the tradition of treating women as property. At the same time they teach women, how wrong decisions and great expectations can mar the lives of women. Marriage is not the end of woman's life. It is not only through marriage that women can achieve completeness in life. Dorothea and Eustacia fail in their marriages due to wrong choices. Women do not have to be idealistic like Dorothea nor passionate and romantic like Eustacia. Both writers reject idealism. They forward the theory, to strike a balance between physical and spiritual needs, in order to live a fuller, peaceful life. Interestingly, they also affirm that men of that time cannot deny the reality of female sexuality. Finally, Women have to be realistic, assertive and self-determined to achieve good results from their marriage.

\section{Bibliography}

Wollstonecraft, Mary. Thought on education of daughters: With reflection on female conduct, in more important duties of life. London, Johnson, 1978.

Austen, Jane. Emma. London: John Murray, 1815.

Adams, Farewell Harriet. "Dorothea and Miss Brooke in Middlemarch. ." Nineteenth Century Fiction 39, no. 1 (1984): 69-90.

Basch, Francois. Relative creatures: Victorian Women in Society and the Novel. New York: Shocken, 1974.

Beer, Gillian. George Eliot. Bloomington, Indiana, 1986.

Bentham, Jeremy. An introduction to the principles of morals and legislation . 1789.

Eliot, George. "Middlemarch." 29-30. London: Penguin, 2000.

Daleski, Matthew Hillel. Thomas Hardy and Paradoxes of love. Columbia: Columbia University of Missouri, 1997.

${ }^{57}$ Morgan, Simon. A victorian woman's place. Public culture in the nineteenth century. (New York: Taurus Academy, 2007), p.154. 
Darwin, Charles. On the origin of species. By means of natural selection. London: John Murray, 1859.

Growing, Laura. Domestic Dangers. USA: AMazon, 1996.

Hardy, Thomas. "The Return of the Native." London: Penguin, 1999.

Neale, Catherine. Middle March. Penguine Critical Studies. London: Penguin, 1989.

Malius, Jill. Unstable Bodies: Victorian Representations of Sexuality and Maternity. Manchester , UP, 1995.

Mill, Stuat John. Essays on Economics and Society. London, Roultedge, 1967.

Morgan, Simon. A victorian woman's place. Public culture in the nineteenth century. New York: Taurus Academy, 2007.

-. A Victorian Women's place. Public Culture in Nineteenth Century. New York: Taurua Academy, 2007.

Peck, John. How to study a Thomas hardy Novel . New York: Macmillan, 1987.

Perkins, Joan. Victorian women. London, Cambridge, 1993.

Schwartz, Danial R. The transformation of English Novel 1890-1930 studies in Hardy, Conrad, Joyce, lawrence, Forster, Woolf. 2nd Edition. London: McMillan, 1995.

Sengupta, Chittaranjan. Thomas Hardy: The novelist of Tragic Vision. New Dehli: Bahri Publications, 1994.

Smith, Adam. The Wealth of Nations . UK: Methuen \& co, 1922.

Richard, Daniel. Victorian Peopleand Ideas: A comparison for the readers of Victorian Literature. New York, 1973. 